\title{
Application of the Principle of Public Hearing in Media in China
}

\author{
Lijuan Wang \& Chunhong Zhang \\ College of Law and Humanities, Tianjin Polytechnic University \\ Tianjin 300384, China \\ E-mail: wanglijuan.777@163.com
}

\begin{abstract}
Fundamental significance of the principle of public hearing lies in the fact that it provides a platform for social supervision, which is more propitious to judicial fairness. As a supervision entity with authoritative social functions, modern media brings harmony and conflicts together in the process of application of jurisdiction in different fields of media, but they haven't got integrated so far. This paper aims at application of public hearing in media context and elaborates respectively different aspects of facilitation and limitation. And finally, several thoughts are discussed in terms of integration between jurisdiction and media.
\end{abstract}

Keywords: Public hearing, Judicial fairness, Media, Integration of horizons

Public hearing, an authoritative standard of supervising and ensuring judicial fairness, together with the modern media that pursues similarly social fairness as the goal of value, has, matter of course, constructed a harmonious standard of "recommendation of virtuous persons with no taboo of relatives" in the present "sociology era". However, there exists objectively a congenital difference between jurisdiction and field perspectives of media, so contradiction and conflicts will inevitably exist in understanding and practicing the principle of public hearing in China. Therefore, integration of this principle with field of media seems extremely important. From a certain perspective, this is an objective need of constructing and developing democracy and the rule of law in the society.

\section{Summary of public hearing in China}

\subsection{Legislative backgrounds of the principle of public hearing}

The principle of public hearing originated from "Of Crimes and Punishments", which was the masterpiece of Beccaria, the Father of Italian modern criminal laws in the $18^{\text {th }}$ Century. In this masterpiece, there is such a rhesis, which warns people all the time, "Hearing should be public, and proof of a crime should be public, so that public opinions which might be the unique socially restriction means could restrict mightiness and desire." Since this famous inference came out, many countries have included and adopted it in their legislation and jurisdiction. For instance, the Sixth Amendment of the Constitution of the United States, which was passed in 1791, was stipulated as follows, "Among all criminal actions, a defendant is entitled to a rapid public hearing by the jury in the state and region where a crime happens". Simultaneously, this was the earliest legislative form of expression in public hearing. In 1948, United Nations issued "Universal Declaration of Human Rights", and stipulated in the Tenth Article, "Every one is entitled equally to an equitable and public hearing by an independent and impartial court, so that his or her rights and obligations can be confirmed and any criminal charge can be decided upon him." By then, public hearing had become an internationally recognized principle.

"Constitution" in China was clearly stipulated in 1982, "All case hearing by the People's Court should be public except for special cases specified by the law". Furthermore, "Criminal Law", "Code of Civil Law", "Administrative Procedure Law" and "Organic Law of the Courts" all without exception have absorbed the principle of public hearing in their general provisions. Therefore, it is obvious that, public hearing is not only a significant standard in the lawsuit system in China, but has escalated to be a constitutional principle.

\subsection{Fundamental content of the principle of public hearing in China}

Briefly speaking, the so-called public hearing refers to the fact that, all activities that might affect the final decision of a 
legal case should be public in the court. According to the existing law in China, there are mainly the following three aspects about the principle of public hearing. Firstly, the hearing process should be public. Activities of a case hearing should include submission of a proof, investigation and confirmation etc. All should be publicized in the court until it is particularly specified by the law. The public are allowed to sit on and the news media are allowed to interview and report. It is thereby known that, direct and open public auditing and indirect and open media supervision both are merged into the principle of public hearing. Secondly, the result of a hearing should be public, namely, public sentence, which means that a judgment and facts and reasons for such a judgment should be publicly declared. At the same time, journalists are allowed to make a report, and the court should also make a public announcement timely. Thirdly, the targets of a sentence should be public, which not only include litigants, but also the society.

\section{Harmonious standard of public hearing and media supervision}

\subsection{Public hearing and media supervision have the identical value standard}

According to standards of "Universal Declaration of Human Rights" and "International Covenant on Civil and Political Rights", judicial fairness should include such factors as protection of the law, hearing by a qualified court, an independent and impartial court and a fair and public hearing. In short, public hearing is one of the requirements of judicial democracy per se, and also a powerful weapon for realizing judicial fairness, which exactly have the same role as media supervision (Note 1). In virtue of different carriers, media supervision demonstrates different expression forms. Free expression of public opinions has become the channel and sign for a citizen to realize expressing his or her right to freedom, and furthermore, he or she may share sufficiently the right to freedom of opinion and expression. Meanwhile, this is exactly the significant content of the fundamental rights of citizens in China, a significant guarantee and reflection to implement rule by law and constitutional governance. In a certain meaning, it is expression of right to freedom that the legitimacy of media supervision on jurisdiction gets explained. Therefore, value pursuit of media supervision and public hearing is reflected in the same standard, namely, to put interests of the public in the first place, to strengthen transparency of the jurisdiction, to realize fairness through public hearing, to extensively accept social supervision, and furthermore, to realize social justice and fairness.

\subsection{Public hearing in media supervision has its historical inevitability}

It is obvious from the historical track of public hearing that, accompaniment of public hearing and media supervision has not only been due, but more be necessary. Tracing back to 1980s when was the early period of public hearing in China, the "public" form of hearing was more confined to the judges and both litigants. In order to realize the public hearing in its material meaning, the courts of law of all levels have always been exploring so as to enlarge public scope of a hearing and to enhance transparency of a court hearing and public credibility of judicial fairness. As it goes, "Ten years for sharpening a sword". Similarly, it was not until the end of 1990s that some local courts began to utilize the popular medium TV to broadcast a live court hearing. For example, the case of collapse of Hong Bridge in Qijiang County Chongqing Municipality concerned all round the whole nation not only aroused extensive attention of the public, but also acquired obvious social effects, because the live broadcast of its hearing was presented to the public without missing of any detail, which was an omnibearing embodiment of the principle of public hearing.

It is proved by practice that, public hearing of jurisdiction in hand with media not only enables such legal professionals as judges, procurators and lawyers to encounter supervision of the whole society, but can satisfy and realize right of information and supervision on the side of citizens to an utmost extent. Therefore, we may regard integration of public hearing with media supervision as a necessity of reform in judicature mechanism and social progress. Just as the great American judge Brandeis said, "Sunshine is the best preservative", we may also believe that, public hearing and media supervision can not only be considered "preservative", but can be distinguished as "a skilful doctor that can cure social diseases".

\section{Conflicting constraints between public hearing and media supervision}

Media supervision has an irreplaceable positive promotor action on growth of public hearing. However, just as a coin has two sides, there often happens contradiction between public hearing and media supervision.

\subsection{Different field perspectives lead to different responses to a legal case}

As two different social effective forces, jurisdiction and media hold different field perspectives. They not only respectively play different social roles, but follow distinctive survival rules. As for jurisdiction, it is often reflected whether the chain of proof is complete? However, media focus on whether the bottom line of morality has overstepped? Then, jurisdiction and media entangle with each other in the complicated sense and sensibility, and any yielding or concession is impossible on the two sides.

When a legal event happens, the "truth" from the perspective of law and "truth" pursued by media might not be totally identical. The "truth" of the former is usually defined as "a standard beyond reasonable doubt". In other words, it refers to the fact finally asserted by a court in the process of a judicial litigation, and it is a new fact adjusted and remodeled 
by Law of Evidence, Procedural law and Substantive Law. Although it may not be the fact itself, it has an utmost and "reasonable acceptability". On the contrary, the "truth" pursued by media is more a "fact" from a comprehensive judgment by combination of one's perception and experiences. It is often assessed and disputed based on morality, which shapes a sharp contrast with a neutral position of jurisdiction to judge right and wrong.

\subsection{The identity of "mouthpiece" of media may result in a politicalized trend of hearing}

According to the economist Lindblom, authority, exchange and persuasion are the three fundamental factors of social domination. If we regard law as the corresponding entity of "authority", then public opinion is a corresponding entity of "persuasion". Broadly speaking, public opinion is also a control mechanism. However, in reality, public opinion which has the greatest influential scope and extent is more dependent on report and transmission of media. Therefore, Schramm, the Great Master of mass communication vividly compares media to a "social radar", and regards it as the "vane" and "barometer" of social development. Again, media have an inherent advantage of "mouthpiece".

All media behaviors of supervision on judicial activities haven't been totally brought into a legal system track, so some media do generate a politicalized trend due to their identity of "mouthpiece". That is, media resort to the political power to invade judicial space, the essence of which is to arouse attention of "the department concerned" by means of media disclosure and report. Then, issues will get resolved after involvement or written comments of immediate leaders. This is just as the American scholar Benjamin summarized the mode of Chinese media's influences upon jurisdiction after his inspection of Chinese jurisdiction: media affect top authorities, who affect the court and further affect the jurisdiction. Mr. He Weifang points out pointedly official newspapers are a modern republication of classical official news and media to a certain extent, which follows the will of the organ they are attached to but not a discipline of journalism. As a consequence, the judicial department is unable to handle a case independently, but may make unfair and even illegal judgment under stress of politics and the society. For instance, in the case of "Zhang Jinzhu", he, who shouldn't have been sentenced to death, was sentenced the death penalty just because of fierce attack of media and pressure of relevant authorities once and again. Such a negative effect of judgment by the media tends to result in a negative concept that the society needs ruling by people not by law, and in a belief that law performs practically no function at all. If media supervision is not timely brought into a track of rule by law, then intervention of the media without rule of law might lead to a politicalized judgment. As a result, consciousness of rules of law which have been implanted into people's mind disappear, so it's unlikely for a sound judicial system to exist because of its leak. Furthermore, it's difficult for the social fairness and justice to get implemented.

\section{Several thoughts on integration of jurisdiction and media}

How to coexist harmoniously and stably and how to attain an integration of fields for jurisdiction and media?

The authors believe that the key is to formulate a department law that can adjust relations between jurisdiction and media, and that should be formally brought into the track of rule by law. A legal means should be applied for a precise guarantee of functioning space between media and jurisdiction, and to avoid randomness and uncertainty in practical operation. Simultaneously, rights and obligations of jurisdiction and media should be made clear in presence of legal news. Even if a conflict appears between them, a legal means should be applied to resolve the dispute, and the truth should be to the law. For instance, the manner and time in which the media interferes with a case; scope and extent of disclosure of judicial documents that the media may come into contact with; under what circumstance the judge has the obligation to explain; when the media report legal news, they should distinguish clearly the truth and viewpoints of the media, separation of a report and their comments, and relavant legal obligations, etc. All in all, the department law should not only restrain activities of the media to confirm to the standard, but should also become a legal proof for ensuring supervision of the media on activities of jurisdiction. Meanwhile, this department law should also create a more optimized law-related environment for integration of jurisdiction with fields of the media.

Then, contradiction between media and jurisdiction can be alleviated from the perspective of judicial procedure. The court should make some adjustment in certain judicial procedures to eliminate inappropriate or unfavorable influences by the media per se, mainly including the following several means. Firstly, the court can avoid a case in a vehement condition of public opinions by postponing the hearing. According to the existing procedural law in China, a postponed or suspended hearing can both be applied into such a legal case, and by means of such a roundabout hearing, unfavorable influences from media public opinions on the case can be reduced to its minimum. Of course, the precondition is that the party involved can be guaranteed a rational and fair hearing within the legal term. Secondly, the hearing venue should be changed and furthermore the designated jurisdiction should be determined, because regional variation might result in different influences of media in different areas. If a case is transferred from "a harder-hit area" to an area with relatively less influence, then unfavorable impacts of media on jurisdiction can be evaded to a certain extent. Thirdly, it should be strictly restricted that judicial officials and litigants release any information about a pending case to the media. A judicial official should not only keep to the professional secrets, but should also defend judicial independence. To maintain an appropriate distance with the media is what is required in $<<$ Professional Ethics of Judges $>>$ and $<<$ Professional Ethics of Prosecutors $>>$. Different litigants have different opportunities to approach to the 
media. Therefore, if the media can't provide equal statement opportunities to the two parties, then it would be certain that interests of the other side will be affected, and simultaneously the trend of public opinions to lean to one side will be brought about.

Finally, considering professional quality and ethics of judicial and media practitioners, integration of jurisdiction and media is also an effective approach to relieving conflicts between them. In recent years, some measures and systems for realization of judicial independence and fairness have come on, and some practitioners who have knowledge of law work on the front line of media, which at least can avoid friction caused by a large part of professional differences. Self-discipline of media will also provide guarantee for standardized journalism and communications.

Meanwhile, it should be noted that, no matter how the media and jurisdiction get coordinated, their contradiction may still emerge or even intensify in a particular situation. Realization of their integration once and for all by placing hope on the legal system is unrealistic. It's only possible for us to try to search for an equilibrium point between them during a dynamic adjustment and mutual friction. However, the goal is no more than a guarantee of rational supervision of the media on jurisdiction and also a guarantee of complete implementation of judicial fairness.

\section{References}

Cesare Beccaria. (1993). On Crimes and Punishment, translated by Huang, Feng. Encyclopedia of China Publishing House, 2.

Don Black. (2002). Sociological Justice, translated by Guo, Xinghua. Beijing: Law Press, 116-117.

Fairness of Civil Jurisdiction and Its Institutional Guarantee (Summary of Symposium). (1999). Legal Research Frontiers (Vol. 3). Beijing: Law Press.

He, Weifang. (1998). Three Sujects of Jurisdiction and Media. Law Science, (06).

Jiang, Wei. (1999). Evidence Law. Beijing: Law Press, 117.

Lindblom. (2004). Politics and Markets, Political and Economic System. In Wang, Yan. Study on Relations between Media Supervision \& Judicial Independence. Beijing: China Logistics Publishing House, 260.

Renmin University of China Law School. (1982). Selected Collection of Chinese and Foreign Constitutions. People's Press, 228.

Wang, Yan. (2004). Study on Relations between Media Supervision \& Judicial Independence. Beijing: China Logistics Publishing House, 345-360.

Yin, Li. (2000). On Legal Constraints in Supervision by Public Opinions. Journalistic front, (12).

Zeng, Yan. Relations between Media Supervision and Judicial Fairness From the Perspective of Sociology of Law. Modern Business, (27).

Note 1.

Media supervision refers to disclosure, report, comment or attack of such mass media as newspaper, publications, broadcast, TV and network on all sorts of violation of law, activities against discipline, and especially violation of law malpractice or malversation of the national civil servants. 